\title{
Os volteios do folclore em $O$ cheiro de Deus
}

\author{
Elaine Alves Testoni
}

RÉSUMÉ: Cet article analyse le roman O Cheiro de Deus, de Roberto Drummond, en soulignant la présence d'éléments fantastiques dans le récit. Dans cet ouvrage, le fantastique dialogue avec la tradition littéraire, c'est-àdire avec les classiques et la littérature érudite, ainsi qu'avec les récits du floklore populaire.

\section{PALAVRAS-CHAVE:}

\section{Introdução}

O objeto selecionado para realização deste trabalho é o último romance do escritor Roberto Drummond, O Cheiro de Deus, obra da qual destacamos aspectos que permeiam a presença de elementos fantásticos na narrativa.

Nosso interesse originou-se do desejo de investigar os efeitos de sentido específicos no romance em estudo, tendo em vista que o fantástico adquire uma função especial e possibilita um profícuo diálogo com a tradição literária, não só com os clássicos, com a literatura erudita, mas também com as narrativas do folclore popular, tais como os contos de fada e os relatos de transmissão oral do folclore brasileiro (saci; lobisomem). Iniciamos o conhecimento da obra do escritor mineiro por meio de seus contos e ficamos curiosos para conhecer seu último romance, divulgado pela mídia e bem recebido pelo público leitor.

O Cheiro de Deus é um romance que aborda os desencontros da família Drummond no Brasil. A obra gira em torno de Vó Inácia Micaéla, que aparece na narrativa com 65 anos, cega, e que cada vez mais apura seu olfato tentando descobrir qual é o cheiro de Deus.

Elaine Alves Testoni é professora da Faculdade Anchieta, São Paulo. 
A narrativa se passa principalmente em dois locais: Cruz dos Homens (na região do Contestado, entre Minas Gerais e Espírito Santo) - cenário que dá início à saga entre o PSD (partido do clã dos Drummond) e UDN (liderado pelo Coronel Bim Bim e seus seguidores) -, e Belo Horizonte, onde a família Drummond passa a viver após seguir as recomendações do Dr. Hilton Rocha, médico de Vó Inácia, com o intuito de poder curar a cegueira da matriarca. A cidade também é marcada pela tradição de "refúgio de tuberculosos", conceito que vai se perdendo no decorrer da história.

Toda a trama gira em torno dos Drummond, família em que os casamentos incestuosos são freqüentes e todos os homens têm nome de uísque, representando a fixação dos seus parentes com a linhagem escocesa.

Apesar de longo, o romance apresenta uma estrutura bastante envolvente, devido à incessante ação que brota de suas páginas e o diálogo evidente com o plano histórico, político e mítico.

A narrativa exibe a recorrência de elementos fantásticos e suas mais variadas formas de manifestação, desde a carismática figura do lobisomem, até a presença de fantasmas e de personagens que se metamorfoseiam, além da recorrência da figura do duplo na maioria das personagens manifestada por meio de uma espécie de desdobramento (a Catula negra e a branca, a loucura de Vô Old Parr, a beleza física de Satã em contraposição a seu caráter diabólico, a mediunidade da Cigana Carmen, o jogo de amor e ódio que une - e ao mesmo tempo separa - Vó Inácia Micaéla e Coronel Bim Bim).

Desde a literatura clássica pode-se verificar a presença do fantástico. Nas tragédias gregas já tínhamos a interferência de seres de ordem divina na ação das personagens em cena com o objetivo de demarcar as fronteiras entre o sagrado e o humano, demonstrando a necessidade da interferência dos imortais para a manutenção da ordem, do equilíbrio e da harmonia do cosmos. No Romantismo, o fantástico adquire uma outra função, cabendo destacar a afinidade entre o pendor romântico ao escapismo e a eleição do fantástico como uma das vias de fuga da realidade, porta de entrada para um mundo de sonho, mistério e caminho para a transfiguração de uma realidade hostil ou indesejada.

O objetivo do trabalho é realizar uma abordagem sobre o gênero fantástico, centrando nossa atenção ao que vem sendo chamado realismo mágico, considerado uma categoria estética e literária própria. Investigar também os elementos fantásticos e a sua relação com o mundo mágico realista do romance, pois a partir dessas observações tomaremos como objeto de análise os elementos folclóricos e traçaremos um paralelo entre as personagens do folclore brasileiro e do africano concomitantemente, porque se mesclam oferecendo uma estreita proximidade.

Analisaremos ainda a religiosidade afro-baiana, que nos servirá de apoio 
para os desvendamentos relacionados ao folclore africano presente no romance, tal qual o mito folclórico embasado na narrativa que nos encaminha para um incessante desejo de determinar as marcas que tais elementos adquirem em $O$ Cheiro de Deus.

Não podemos deixar de considerar em nosso trabalho as transformações sofridas pelo próprio gênero fantástico ao longo de séculos de tradição literária. Apesar de ser possível verificar a interferência do sobrenatural na ordem natural/lógica do mundo em muitas narrativas da literatura universal, é apenas no século XIX que o fantástico alcançará estatuto genérico e passará a contar com um escopo teórico de estudo de suas manifestações, tendências e peculiaridades. É nesse momento que teóricos como Tzvetan Todorov, a partir de um conjunto de narrativas fantásticas, passa a determinar temas e motivos característicos do fantástico, assim como os subgêneros que dele derivam.

"Uma lei fixa, uma regra estabelecida: eis o que imobiliza a narrativa. Mas para que a transgressão da lei provoque uma modificação rápida, é preciso que forças sobrenaturais intervenham; senão a narrativa corre risco de se arrastar, esperando que um justiceiro humano perceba a ruptura do equilíbrio inicial. O elemento maravilhoso é uma matéria que melhor preenche essa função precisa: trazer uma modificação da situação procedente, romper o equilíbrio (ou o desequilíbrio)". (TODOROV, 1970, p. 164)

A partir daí, Todorov define: $\mathrm{O}$ fantástico ocupa o tempo da incerteza... é a hesitação experimentada por um ser que não conhece as leis naturais, diante de um acontecimento aparentemente sobrenatural. (TODOROV, 1970, p. 148)

Já para Vax, o fantástico em sentido restrito exige a errupção dum elemento sobrenatural num mundo submetido à razão. (VAX, 1974, p. 14)

\section{Abordagens sobre os elementos fantásticos e o Realismo Mágico}

Em $O$ Cheiro de Deus não encontramos estranhamento por parte do leitor no que tange às freqüentes aparições de seres como o lobisomem, o saci, fantasmas e outros elementos que permeiam a narrativa: loucura, metamorfose, duplo. $\mathrm{O}$ mesmo acontece com o narrador, que já nas primeiras páginas do romance afirma que o sobrenatural é natural em Minas Gerais e conseqüentemente a mesma posição é tomada por todas as personagens que convivem harmoniosamente com o inexplicável. Isso nos leva a 
crer que estamos diante de uma descrição clara de realismo mágico.

As manifestações do realismo mágico segundo Spindler se dão numa estrutura que incorpora diferentes tipos de realismo mágico e mantém, ao mesmo tempo, elos e pontos de contato entre eles. Porém, tais pontos não se apresentam mutuamente exclusivos, pois obras de um mesmo autor podem apresentar diferentes categorias. Tais propostas se classificam de três maneiras: Realismo Mágico Metafísico, Realismo Mágico Ontológico e Realismo Mágico Antropológico, este mais predominante em $O$ Cheiro de Deus, pois sua maneira de descrever os acontecimentos se apresenta em alguns momentos de forma racional e em outros do ponto de vista do elemento mágico, fatores determinantes quando o autor adota ou se refere aos mitos e a história cultural de um grupo étnico ou social.

No romance são apresentados dados correspondentes a essa terminologia, tais como: os habitantes de Cruz dos Homens - na região do Contestado - sabiam da existência do lobisomem e muitos tiveram a oportunidade de vê-lo. O lobisomem apareceu. Andava como um homem e ao ouvir seus uivos, compadre Nico do Degredo pensou em fugir, já as 5 irmãs o receberam tirando rosas vermelhas de uma cesta e jogando para o lobisomem, do alto da varanda... (DRUMMOND, 2001, p.111)

Até mesmo os que se diziam mais valentes, em determinadas circunstâncias precisavam mudar de estratégia.

"O coronel satisfazia uma necessidade velha como a história dos homens debaixo de uma árvore. O lobisomem o atacou, pondo em fuga os 40 jagunços que o protegiam e não dispararam seus rifles, obrigando o coronel a correr com as calças nas mãos e pedir asilo a Padre Zé Lopão na casa paroquial”. (DRUMMOND, 2001, p.112)

Em relação a fantasminha Emily, não só era vista pelos habitantes do castelo de Vó Inácia Micaéla, como também era tratada como se fizesse parte da família Drummond, uma vez que todos a respeitavam e a tratavam com muita simpatia: Vó Inácia ficou amiga da fantasminha inglesa. Emily sentia tanta saudade dos pais e dos irmãos, que eram fantasmas e moravam em Londres, que escreveu uma carta à Rainha Elizabeth II... (DRUMMOND, 2001, p.199)

Tamanha era a afetividade de Emily, que foi escolhida para enaltecer a cerimônia matrimonial - Catula usava o vestido de noiva que Vó Inácia Micaela usou para se casar com Vô Old Parr e tinha uma única dama de honra, Emily, a fantasminha, que conseguiu um passaporte especial com a Rainha Elizabeth II e veio da Inglaterra. (DRUMMOND, 2001, p.374)

As personagens do romance estão envolvidas mutuamente por cami- 
nhos freqüentemente inexplicáveis, em que a fantasia e o real se mesclam sem delimitações, criando no leitor a sensação de um imaginário coletivo Era um castelo como os castelos dos Contos de Fada. Nas noites de lua, com suas paredes levemente pintadas de azul, ganhava um toque de mágica. Parecia pertencer a um mundo de faz-de-contas... (DRUMMOND, 2001, p.116) Esse mundo de faz-de-conta manifesta-se em várias personagens:

"Os serviços domésticos do castelo, incluindo a cozinha, Tia Viridiana entregou aos 7 Anões... O anão Alegria tinha sido cozinheiro de um circo e de um restaurante no Rio de Janeiro... tinha medo de cair na panela de feijoada e não poder se casar com a Dona Baratinha, que tinha fita no cabelo e dinheiro na caixinha, por isso usava suspensórios especiais inventados por Tio Red Label". (DRUMMOND, 2001, p.179)

Notamos que as alusões feitas aos contos de fadas (elemento maravilhoso) não se restringem apenas aos vestígios mágico-realistas do espaço em que se inserem, mas também a um forte e eloqüente senso de humor e ironia, que faz essas mesmas personagens serem banalizadas fora do seu contexto literário.

Na literatura latino-americana, o Realismo Mágico Antropológico compartilha de maneira mais ampla, abrange o caráter temático e formal englobando o estranho, o inexplicável, o grotesco e também com violência, deformidade e exagero. Aplica-se também a existência de uma conscientização mágica nas personagens, característica que o liga à cultura popular.

A obra em análise proporciona ao leitor traços que norteiam a cultura popular, mas basicamente o folclore, cujas marcas podemos perceber nas recorrentes descrições de elementos advindos de tal cultura. Faremos, então, um breve percurso sobre o folclore para esclarecermos algumas curiosidades e ao mesmo tempo traçarmos um paralelo que norteará nossos estudos sobre a origem de certas personagens do romance.

\section{Folclore}

Tal como a língua e a história, o folclore é um conjunto de manifestações da cultura popular tradicional que retrata a alma de um povo, exprimindo sentimentos e valores estéticos que muitas vezes influenciam as expressões mais elaboradas da cultura de cada nação.

Os folcloristas admitem que as criações populares servem a múltiplos 
propósitos. Assim, a literatura folclórica, como seus heróis sobre-humanos, seus países maravilhosos e seus seres fantásticos, permite às pessoas escaparem do estreito círculo da vida cotidiana. Essa literatura responde também às grandes indagações do homem sobre sua própria origem e a origem do mundo, sobre sua história e destino. Mostra ainda a utilidade e o sentido das instituições sociais, ao mesmo tempo que instrui sobre o comportamento social correto. Desse modo, o folclore, que nesse sentido se relaciona com o mito, atua como elemento de coesão da sociedade humana.

O folclore difunde-se de maneira permanente, e assim seus elementos são ao mesmo tempo estáveis e acentuadamente mutáveis. Em termos gerais, é possível afirmar que o acervo folclórico universal é constituído pela literatura, pela música e a dança, e por criações de ordem material.

Nos exemplos da literatura oral no Brasil contam-se poesias (cancioneiro, desafios, testamentos de Judas), narrativas (contos, fábulas, mitos e lendas), enigmas e adivinhas, anedotas, trava-línguas, pregões, inscrições, como as de caminhão, os abecês e, em geral, a literatura de cordel. As tradicionais histórias sobre seres fantásticos fazem parte do folclore brasileiro e são transmitidas oralmente de geração para geração. Os seus principais personagens têm origem indígena ou européia: Boitatá, Boto, Caipora, Cuca, Curupira, Mula-sem-cabeça, Iara, SaciPererê, Lobisomem, etc.

Focalizaremos apenas as duas últimas personagens, pois são de maior interesse para o estudo em pauta, uma vez que contribuem para a ampla e excitante digressão da narrativa.

\section{Saci-Pererê}

Pequeno e barrigudo tem os cabelos e os olhos cor de fogo, um nariz de socó e as orelhas de morcego. Na boca, traz sempre um pito de barro e, na cabeça, uma carapuça vermelha.

O Saci é travesso e brincalhão. Todo o mal feito que acontece durante a noite é atribuído a ele.

O pequeno trasgo, diabrete, que praticava as travessuras dentro das casas na Idade Média, na Europa, deu ao Saci o tamanho e a barriga.

A cor negra é a identificação da participação africana no mito. As orelhas ponteagudas são próprias dos morcegos hematófagos e também uma herança européia dos vampiros da Transilvânia. A cor de fogo dos cabelos e dos olhos é o símbolo da perversidade dos demônios. O capuz vermelho é a indumentária típica dos duendes europeus e é o que dá ao 
Saci o poder da invisibilidade. O pito encontra-se na boca dos pretos velhos e de lá é que vem essa recorrência.

As travessuras do Saci são muitas, algumas delas não trazem prejuízos, outras são de grande perversidade: assobia e pula sobre o lombo das manadas, fazendo-as correr pelo pasto em assustado galope; cavalga e faz tranças nas crinas dos cavalos; tem o poder de ficar invisível quando quer; gosta de esconder as coisas para ouvir os nomes feios ditos pelas pessoas que as procuram; em dia de vento, gosta de girar sobre o único pé, fazendo redemoinhos de poeira.

Dizem que não é difícil vencer o Saci. Basta atirar-lhe um rosário de capim, contudo, o mais eficaz é o Credo. O Saci dá um assobio estridente, solta uma fumaça vermelha e desaparece no meio dela.

É importante lembrar que o Saci é a figura mitológica brasileira que mais se identifica com o mundo infantil. Não se apresenta a elas como um ente perverso, pelo contrário, é camarada e brincalhão. Nas rodas de brinquedo, nas cirandas e nas histórias ele é sempre lembrado.

Em O Cheiro de Deus, o Saci é aludido com base no mito folclórico, no entanto, apresenta algumas características que fogem a sua identidade: é descrito como uma personagem indiferente às pessoas, e se isso não bastasse, ainda lhes presta favores:

“... Catula pediu ao Saci que fosse ver o que estava acontecendo. O Saci era um negrinho da fazenda. Nasceu com uma perna só, o que nunca o impediu de circular como uma aparição por todos os lugares desde que aprendeu a andar, pulando numa perna só. Andava nu e usava gorro vermelho dado por Catula, trocado por um novo quando ficava velho, e era confundido com o verdadeiro Saci e tido na conta de uma aparição" (DRUMMOND, 2001, p.147)

Isso se torna concebível no romance, pois o elemento mágico proporciona caminhos inusitados no que diz respeito à própria manifestação folclórica, e através dela, encontra-se a possibilidade de criar uma certa alegoria aproximando a personagem do enredo - criada com base nas origens folclóricas ao próprio mito, de maneira que haja harmonia nas veredas da narrativa.

"Catula tomou-o sob seus cuidados e o Saci freqüentava a escola primária que Vó Inácia instalou na fazenda, mas não usava roupa como os outros meninos. De forma que, aos 11 anos, quando começou o cerco, o Saci andava nu, pulando numa perna só, e conseguia penetrar no território em volta da fazenda sob o controle do coronel e os jagunços que o viam e rezavam. O próprio coronel resignava-se ao vê-lo". (DRUMMOND, 2001, p.147) 
Apoiado ao romance de maneira sutil e entrelaçado às personagens da família Drummond numa vertente familiar, o Saci abraça as causas drummondianas e conspira contra os inimigos de forma bastante ameaçadora, tornando-se aliado e ao mesmo tempo mensageiro dos perigos que o Coronel Bim Bim e seus comparsas possam oferecer.

A personagem Saci, tal como o mito folclórico, incumbe-se de causar espanto, porém, na narrativa em estudo percebemos que essa proeza nata não é atribuída a bel prazer, pois o negrinho escolhe bem o alvo das suas peripécias, neste caso, todos os que se opõem à família de Vó Inácia Micaéla.

Dessa maneira nos deparamos com uma característica paradoxal, ou seja, para a família Drummond o Saci é tido como uma personagem benéfica, que compartilha do mesmo cotidiano e assume a postura de espião e de certa forma, protetor da fazenda.

\section{Lobisomem}

As raízes do mito do lobisomem são mais antigas do que se pensa. A dualidade do homem besta sempre existiu e a encontramos nas mais variadas mitologias: licantropo na Grécia, versiopélio em Roma, volkdlack eslavo, werwolf saxão, wahwolf germano, obototen russo, hamramr nórdico, loupgarou francês, lobo-homem, lubizon na Espanha e Portugal.

Os antigos gregos já acreditavam que um homem pode se transformar em lobo, sendo famoso o culto Zeus-Licaon, durante o qual os participantes usavam máscaras de lobo e dançavam até atingirem um êxtase que os fazia agir como se o espírito das feras houvesse tomado o corpo.

A mitologia conta que Licaon, para dar prova de devoção, sacrificou uma criança em louvor a Zeus. Tal crime não agradou ao senhor do Olimpo, que lhe impôs um castigo terrível.

Licaon foi levado pelos membros de sua família à beira de um lago. Ali ele foi despido e suas roupas penduradas em uma árvore. Lançado às águas, nadou até a outra margem e penetrou na floresta, onde foi transformado em lobo e viveu nove anos entre uma matilha.

A condição imposta para romper o encantamento foi a de vencer o período de provação, abstendo-se de carne humana. Assim pode voltar à outra margem e, já sob a forma humana, retornar às roupas.

O lobisomem romano já era cultuado, pois a lenda da fundação da cidade conta que Rômulo e Remo, gêmeos fundadores de Roma teriam sido amamentados por uma loba, cuja verdadeira profissão era a de prostituta e recebia esse apelido devido às atividades praticadas. Essa tradição dá origem às festas anuais chamadas lupercais, um culto à fertilidade envolto pela orgia. 
As formas de encantamento do lobisomem se dissipam no tempo e são apresentadas de maneiras distintas.

Se uma mulher dá a luz a sete filhos, o primeiro ou o último será, fatalmente, lobisomem. É fácil identificá-lo, pois é muito magro, macilento e taciturno. Tem geralmente sobrancelhas grossas que se encontram e é bastante peludo nos braços.

Quando os ponteiros do relógio se cruzam, à meia noite, para marcar o início da sexta-feira, quando a lua cheia brilha no céu, ele vai a uma encruzilhada, despe-se, atira-se ao chão e rola na poeira. Poucos instantes levam para que a metamorfose se inicie: o homem se transforma em homem lobo.

O folclore apresenta várias formas para quebrar o encanto ou matar o lobisomem, entre elas, a sua maioria é mágica ou exorcizadora.

Segundo Câmara Cascudo (em sua obra Geografia dos mitos Brasileiros) basta ferir a criatura para que ela sangre, pois o diabo vem lamber o sangue derramado e considera sua parte recebida, no entanto, o desencantador não pode ter nenhum contato com o sangue do lobisomem, caso contrário, tomará seu fado e herdará sua triste sorte. Afirma ainda o folclorista brasileiro que o lobisomem só pode ser morto a tiro se a bala for untada em vela que ardeu em três missas da meia-noite do Natal.

As considerações que fizemos acerca das circunstâncias que permeiam o lobisomem como mito nos faz refletir sobre a posição do autor no que diz respeito à preservação da lenda e a sua relação com o elemento fantástico que situa em $O$ Cheiro de Deus.

Notamos que a personagem do lobisomem na obra alude a alguns pontos característicos da tradição popular oral como a relação paralela entre as formas de encantamento do homem lobo.

Percebemos que há uma recorrência notória à narrativa do lobisomem romano, pois em ambas, as personagens foram amamentadas por uma loba, o que sugere o possível fator de transformação lupina.

"Vó Inácia tinha pouco leite, de maneira que uma loba, conhecida por Lô, tal como a Loba de Roma fez com Rômulo e Remo, amamentou seus quatro filhos homens, até que viveu uma paixão tão tempestuosa por um lobo selvagem, que deixou a fazenda". Vô Old Parr ainda era um homem valente, e tentou evitar que Lô fosse embora e prendeu-a em uma jaula, mas o lobo selvagem, tomado de ciúmes, libertou-a numa noite de lua cheia e atacou Tio Dimple, Tio White Horse, Tio Red Label e feriu Johnnie Walker na mão esquerda”. (DRUMMOND, 2001, p.58)

O autor inclusive cita a passagem que confirma nossas observações; 
entretanto, na lenda romana há uma metáfora da loba que não ocorre em $O$ Cheiro de Deus. Neste, as personagens a identificam como animal dócil e posteriormente hostil em função de um grande amor, o que gera uma certa ironia, pois tal sentimento só é atribuído tão intensamente a seres humanos.

“Tio Johnnie Walker já sabia manejar o rifle e podia matá-lo, mas o deixou ir embora com Lô.

- Por que você não matou o lobo, meu filho? - perguntou Vô Old Parr.

- Porque Lô o ama, papai, e eu gosto de Lô como se ela fosse gente, e não quero vê-la sofrer - respondeu Tio Johnnie Walker". (DRUMMOND, 2001, p.58)

A atitude romântica por parte do lobisomem, a vida boêmia em alguns momentos e a oposição às suas raízes num contínuo impasse entre o bem e mal que assolam a sua personalidade, implicam num contexto que o difere das demais criaturas de sua espécie - ...um lobisomem foi visto andando pelas ruas de Lisboa. Estava bêbado e cantava uma canção tão linda, numa língua que ninguém entendia, parecendo uma mensagem cifrada. (DRUMMOND, 2001, p. 69)

Mesmo se tratando de uma canção aparentemente estranha, o efeito atinge às pessoas como se estivessem enfeitiçadas: ... sabiam a canção do lobisomem, que toda a cidade assoviava e convidava ao pecado, porque acabava com a fronteira entre o Bem e o Mal, o Certo e o Errado. (DRUMMOND, 2001, p.114)

O romantismo do lobisomem desafia o seu poder de sedução:

"O lobisomem apanhou um cravo vermelho no jardim do sobrado de Vó Inácia Micaéla. Na hora, Catula o esperava entrincheirada na varanda no $2^{\circ}$ andar do sobrado, com um rifle nas mãos, e quando o lobisomem atirou o cravo vermelho para ela, disparou o rifle, sem saber que os lobisomens eram imortais". (DRUMMOND, 2001, p.111)

Em meio a solidão, a fera se deixa envolver por palavras abençoadas:

"Era tanta a solidão do lobisomem, tanta a vontade de conversar com alguém, que ele se deixou ficar ouvindo o sermão feito em latim. Padre Zé Lopão acreditou, oh, Deus pai, que aquele lobisomem, diferente de todos os lobisomens, podia ter sido enviado por Deus, para obrigar os pecadores, como o coronel, a cair de joelhos e pedir perdão pelos pecados”. (DRUMMOND, 2001, p.112)

Não obstante as características demasiado atípicas do lobisomem, a 
narrativa ainda propicia ao leitor uma certa comicidade, que reflete a importância e a aceitação da criatura por parte da população do Contestado, uma vez que a boa fama da fera o torna invejável. Surgia um novo herói em Cruz dos Homens e, logo, apareceram nos muros da cidade inscrições feitas a piche, com vivas ao lobisomem. (DRUMMOND, 2001, p.114)

Sem que fizesse nenhum esforço para atingir o eleitorado, o lobisomem ganha até um cargo público em função do seu feito reconhecido pela população - O lobisomem teve sua candidatura lançada, em inscrições feitas a piche nos muros e em panfletos clandestinos, e estava tão popular, por ter dado um galope no Coronel Bim Bim, que foi o vereador mais votado... (DRUMMOND, 2001, p.115)

Outra postura não menos cômica do lobisomem é o fato de comer rosas vermelhas e não fazer nenhuma vítima em toda a sua trajetória de licantropia. Suas atitudes provêm da convicção de espantar, atormentar e até mesmo seduzir as personagens que se sentem atraídas pelo possível envolvimento maléfico da fera, o que nos faz admitir que o lobisomem do romance é vegetariano, posição bastante comprometedora para tal criatura; todavia, em função das atitudes demonstradas no decorrer do enredo, essa mesma posição torna-se compreensível.

As formas de desencantamento reportadas ao homem lobo segundo as lendas folclóricas não são as mesmas pela qual a personagem lobisomem da narrativa em pauta - necessita para se livrar de tal característica. Segundo as premonições da Cigana Carmem, de acordo com as fases da lua o lobisomem poderia encontrar uma moça que acabasse com o seu encanto, porém, teria de ser beijado. Desse modo, nos deparamos com uma atitude contrária às supostas lendas, uma vez que foge as expectativas do leitor, pois tal postura é freqüente em contos de fadas como a Bela Adormecida, em que o príncipe desperta a princesa com um beijo, e não na disposição lupina em relação a uma jovem moça, que ao contrário da tradição dos contos de fadas será predestinada a quebrar o encanto da besta fera.

"Catula ficou tão emocionada que caiu de joelhos diante de Padre Luiz e, tomando em suas mãos, contou em tom de confissão o grande segredo de sua vida, que seu príncipe encantado ou desencantado transformava-se em lobisomem e para livrá-lo da maldição ela devia beijá-lo na boca, enfrentando o risco de ser atacada". (DRUMMOND, 2001, p.298)

E assim se cumprem as previsões feitas pela Cigana:

"O lobisomem tinha bebido uma garrafa de conhaque e cantava em aramaico. Catula escutou seus passos, quando o lobisomem 
TESTONI, Elaine Alves

abriu a porta do sobrado de Vó Inácia e subiu a escada. Viu quando o lobisomem chegou à varanda e ficou parado diante da janela do quarto onde ela estava. Tinha um cravo vermelho na mão... O lobisomem atirou o cravo vermelho na cama e Catula o pegou e pôs no cabelo. Sorriu para o lobisomem como nunca tinha sorrido para homem algum. Com medo de atacá-la, pois o Mal parecia derrotar o Bem em seu coração, o lobisomem deu as costas, mas Catula disse em latim:

- Mane nobiscum, Domine, quia advesperascit! - e aproximou-se do lobisomem e o beijou na boca.

A lua cheia entrou no quarto pela janela e clareou os dois e Catula viu o lobisomem se transformar num homem". (DRUMMOND, 2001, p.404)

Diante de tal particularidade do lobisomem em O Cheiro de Deus, percebemos que apesar de se referir a um elemento maravilhoso cria-se um distanciamento da face lendária, elaborado de maneira instigante, e instaura na narrativa uma tonalidade de sedução e desejo por parte do leitor, que se depara com um homem lobo que a todo o momento questiona a sua condição de criatura e compartilha não somente a dualidade de homem/fera, mas também o posicionamento entre o bem e do mal que lhe é atribuído.

A analogia feita aos contos de fadas mais uma vez se faz presente, pois ao nos depararmos com o envolvimento amoroso entre Catula e o lobisomem nos remetemos à história de $A$ Bela e a Fera. No entanto, o enredo em estudo toma um caminho que perpassa o desfecho de tal conto maravilhoso, pois o lobisomem consegue se isentar do seu triste destino de fera, passa a ser mortal como a sua amada e ambos enveredam sem culpa e sem preconceito no limiar do amor.

\section{Pegadas do folclore africano em O Cheiro de Deus}

A organização das religiões negras no Brasil se faz presente há pouco tempo. As últimas levas de africanos trazidas durante o período final da escravidão (últimas décadas do século 19) foram fixadas, sobretudo em ocupações urbanas, num período em que puderam viver em maior contato uns com os outros, e de certo modo, a eles foram confiados liberdade de movimento devido ao processo de interação que não conheceram antes. Este fato propiciou condições sociais favoráveis para a sobrevivência de algumas religiões africanas, com a formação de grupos de culto organizados.

Muitas dessas religiões foram e ainda são citadas em diversas manifestações de arte. Na literatura brasileira, obras como Jubiabá e Mar Morto, de 
Jorge Amado, O tempo e o vento, de Erico Veríssimo mencionam a umbanda, o candomblé e outros cultos como forma de refúgio para várias etnias ou mesmo a fim de representar a raça negra e fazer prevalecer os predomínios de sua influência e cultura.

O enlear dos fatos narrados em $O$ Cheiro de Deus nos faz perceber que a crendice é mencionada de diversas maneiras e dissipa pela obra nuances de catolicismo, magia, misticismo, que posteriormente vincular-se-ão ao candomblé, cujas origens refletem fortemente nas transformações sofridas pela personagem Catula.

Tal personagem nos é descrita como branca, de cabelos fulvos e olhos verdes; contudo, essas características sofrem bruscas modificações quando uma frente fria vinda da Argentina se aproxima, pois Catula sente um calafrio como a febre do incesto, espirra três vezes e vira uma negra.

A metamorfose de Catula, a princípio não é aceita por algumas personagens, como a própria mãe da jovem que admite a repugnância pela cor negra da filha e luta com tais frentes frias como forma de tentar manter a condição de branca da moça.

"Mais calmo, Tio João Manuel levou Catula ao médico e iniciaram uma peregrinação percorrendo os especialistas de pele, onde quer que existissem no Brasil, na Argentina e nos EUA e nenhum deles decifrou o mistério, mas todos concordaram que a única maneira de evitar que Catula ficasse negra era proibir que as frentes frias chegassem ao Brasil vindo da Argentina. Tia Rose passou a sofrer de uma neurose contra a negritude de Catula e fazia novenas para o Menino Jesus de Praga evitar as frentes frias que viessem da Argentina”. (DRUMMOND, 2001, p.89)

A dualidade dos atos de Catula se mostra de forma instigante, uma vez que as diferentes condutas apresentadas por meio de cada caracterização percorrem caminhos inversos. Quando branca, sua postura diante das outras personagens, principalmente masculinas é de serenidade, pudor, respeito, simplicidade. Já negra se torna audaz, ousada, corajosa e acima de tudo possuidora de uma sensualidade e beleza inexplicáveis.

O grande fio condutor da personalidade negra de Catula se deve basicamente a Iansã, orixá importante do candomblé, que representa a deusa dos ventos e das tempestades, dos raios e dos mortos e principalmente do erotismo, fator responsável pelo desejo assíduo de sexo reportado com menos intensidade para o cultivo do amor.

"Quando se transformava numa negra, os olhos seguiam sendo verdes, mas tudo o mais mudava em Catula. Tudo era dança. Tudo 
TESTONI, Elaine Alves

era festa. Tudo era alegria. Tudo era dengo. Tudo era canto. Tudo era sexo. Tudo era riso. Tudo era samba. Surgia então a Catula de Iansã, que não acreditava no pecado nem na culpa, amava dançar e cantar, ria por um nada, ao contrário de Catula branca". (DRUMMOND, 2001, p.87)

Quando a Cigana Carmem leu a mão de Catula pode ver a triste predestinação que rondaria os nebulosos devaneios da caminhada incansável à procura da possibilidade de livrar-se de tamanha tarefa. Além de ter de beijar um lobisomem, também estaria privada do íntimo contato masculino até que sua missão fosse cumprida porque com exceção da criatura, nenhum homem se atreveria a realizá-la como mulher, pois todo aquele que tentasse tão relutante ação, ao vê-la nua conseguiria somente enaltecêla e rezar como se fosse para uma virgem ou divindade. Era sempre assim: quando a viam nua, como branca ou como negra, os homens caiam de joelhos aos pés de Catula e, em vez de amá-la, rezavam para agradecer a Deus e a Exu por Catula existir. (DRUMMOND, 2001, p.94)

A incansável beleza de Catula proporciona novas tentativas:

"Quando Bartô abriu os olhos e viu Catula de Iansã nua, clareada pela lua da Bahia, caiu de joelhos aos pés dela e começou a rezar em nagô e, diante de Catula de Iansã nua, dançou e entrou em transe e os malandros da beira do cais, os boêmios, os mestres dos saveiros e os capitães de areia, atraídos pelo grito em nagô de Bartô, viram Catula de Iansã nua e negra, com os olhos verdes de uma gata, e também caíram de joelhos, cada um rezando à sua maneira, e foram os primeiros a descobrir que Catula era uma divindade..." (DRUMMOND, 2001, p. 99-100)

Mas o insucesso ainda paira sobre os homens. Buchanan's ficou nu e Catula pediu que fechasse os olhos e quando Buchanan's abriu os olhos e viu Catula nua, caiu de joelhos e pôs-se a rezar uma Ave-Maria... (DRUMMOND, 2001, p.106)

Em meio ao espaço vivido por Catula também percebemos a presença da personagem Nanã Boruquê, uma Mãe-de-Santo negra que orientará os caminhos de Catula Iansã aos cultos do candomblé; no entanto, o nome dessa Mãe-de-Santo não é aleatório porque mais uma vez a narrativa se depara com elementos relacionados a essa religiosidade africana. No candomblé Nanã Boruquê é o manifesto da purificação astral. É o Orixá da chuva, que promove a limpeza e a purificação da atmosfera, elimina o negativismo, propiciando assim, melhores condições de vida aos homens. Deusa dos rios e lagos é a mais velha das iabás (orixás femininos). 
A dupla caracterização de Catula fez com que o autor pudesse remeter ao candomblé como forma de enaltecer o culto africano e firmar o papel do negro na sociedade, uma vez que a personagem teve que lutar contra o preconceito alheio, mas também pode mostrar a coragem e determinação da raça negra em alguns momentos em que Catula Iansã se deparou com perigos.

“... transformou-se, de loura que era, numa negra, e o jagunço disfarçado de cego ficou tão assustado com o que viu, acreditando que Catula era o Demônio, que deixou os revólveres cair e fugiu correndo. Os três homens que estavam na fila eram também pistoleiros enviados pelo coronel Bim Bim e também fugiram na hora”. (DRUMMOND, 2001, p.255)

Mais uma vez a opção de deixar Catula definitivamente negra confirma a predileção do autor pela figura que se mostra sensual, com ânsia de vencer obstáculos e encontrar a felicidade. Tal qual um manifesto contra o racismo, em que a raça negra se apresenta de forma vitoriosa em relação aos que lutam contra os direitos de igualdade e as condições étnicas de sobrevivência. Dessa maneira, quando o dia nasceu Tio Johnnie Walker viu que Catula tinha ficado negra para sempre e que ele seria mortal como todos os homens. (DRUMMOND, 2001, p. 405)

\section{Conclusão}

Ao estudarmos os elementos folclóricos da obra pudemos traçar um perfil caracterizando-os no folclore brasileiro e africano. Contudo percebemos que apesar da dissociação de características e as diferentes origens, as personagens folclóricas do Saci e do lobisomem também compreendem uma particular fonte de aproximação no que diz respeito aos vestígios de traços africanos.

O Saci, tipicamente brasileiro, apresenta clara ligação no que se refere a sua cor negra. Já o lobisomem mantém íntima semelhança ao loup-garou quebequense, pois este possui uma forte relação com a religiosidade católica, e de forma um tanto sutil e até mesmo irreverente, o lobo homem do romance possui uma forte atração pelas orações em latim e se porta como um súdito de Deus nos momentos em que o padre lhe concede a benção, a fim de salvar a sua alma pecadora porque a criatura se mostra aparentemente influenciada por uma força maior voltada mais fortemente para o bem do que para o mal. O lobisomem só não invadiu a casa paroquial por circunstâncias de Padre Zé Lopão, que ousou abrir a janela da casa paro- 
quial e encará-lo com um crucifixo de madeira nas mãos, e disse em latim, Seja bem-vindo à casa do Senhor. (DRUMMOND, 2001, p.112)

Em relação à linguagem utilizada pelo lobisomem podemos perceber que o narrador faz alusão a uma passagem bíblica e ao mesmo tempo instaura um certo tom irônico quando afirma que o homem lobo desconhece a língua dos homens; no entanto, a criatura entende perfeitamente a língua dos padres, posição que aproxima a fera de uma doutrina cristã. O lobisomem entendeu o que o padre Zé Lopão disse. Não falava a língua dos homens nem a língua dos anjos, mas falava a língua dos padres. (DRUMMOND, 2001, p.112)

A postura maléfica imposta ao lobisomem é questionada nos vários momentos em que o narrador apresenta pistas expondo o possível lado bom e humano da fera, e instaura no leitor o sentimento de compaixão, pois a criatura demonstra sua boa índole escondida numa carapaça sombria e obscura. Padre Zé Lopão acreditou que alguma coisa era doce no lobisomem e recriminou-se em voz baixa, Deus me perdoe pelo amor de Deus. Acreditou que, por trás de tudo que o lobisomem tinha de horrível e de terrível, os olhos guardavam lembranças dos olhos de um homem... (DRUMMOND, 2001, p.115)

Diante da recorrência de elementos do folclore africano e a iminência das demais personagens folclóricas analisadas no romance, concluímos que tais atribuições possuem considerável importância, embora se apresentem aparentemente satíricas e com certos indícios de ironia.

O realismo mágico contribui de forma imprescindível para mascarar as referências conferidas a esses elementos de forma aparentemente ingênua, envolta de artifícios usados pelo narrador de forma sutil, mas com o intuito de atingir a sociedade preconceituosa e moralizante das décadas de 40 a 60 .

\section{BIBLIOGRAFIA}

ACQUAVIVA, Marcus Cláudio. Lendas e tradições das Américas. São Paulo: Hemus, 1977.

ARAÚJO, Carlos. ABC dos orixás. São Paulo: Círculo do Livro, 1993.

CASCUDO, Luís da Câmara. Geografia dos Mitos brasileiros. Rio de Janeiro: José Olympio, 1947.

Antologia do folclore brasileiro. 4 ed. São Paulo: Martins, 1971.

. Dicionário do folclore brasileiro. Rio de Janeiro: Instituto Nacional do Livro, 1962. 
Os volteios do folclore em 0 cheiro de Deus

CHIAMPI, Irlemar. O realismo maravilhoso. São Paulo: Perspectiva, 1980 (Debates, 160).

DRUMMOND, Roberto. O Cheiro de Deus. Rio de Janeiro: Objetiva, 2001. LOBATO, José Bento Monteiro. O saci. São Paulo: Brasiliense, 1961.

PAES, José Paulo. Os buracos da máscara.Antologia de contos fantásticos. São Paulo: Brasiliense, 1985.

Revista ABC do Destino. Ed. Globo - Junho 19991

Revista Brasileira de Folclore. ANO II / No 3 Maio/Agosto de 1962

RIBEIRO, Maria de L. Borges. Folclore. Biblioteca Educação é Cultura. Rio de Janeiro: Bloch, FENAME, 1980.

RODRIGUES, Selma C. O fantástico. São Paulo: Ática, 1988 (Série Princípios).

SPINDLER, William. Realismo mágico: uma tipologia. Inglaterra: Universidade de Esses, 1993.

TODOROV, Tzvetan. As estruturas narrativas. Trad. Leyla Perrone-Moisés. São Paulo: Perspectiva, 1970.

VAX, Louis. A Arte e a Literatura Fantásticas. Trad. João Costa. Lisboa: Arcádia, 1974. 